\title{
PENGARUH TERPAAN INFORMASI RISET MELALUI WEBSITE www.ppet.lipi.go.id TERHADAP SIKAP MAHASISWA MENGENAI PENELITIAN
}

\author{
Noorfiya Umniyati ${ }^{1}$, Purwanti Hadisiwi ${ }^{2}$, dan Jenny Ratna Suminar ${ }^{2}$ \\ ${ }^{1}$ Lembaga Ilmu Pengetahuan Indonesia \\ ${ }^{2}$ Universitas Padjadjaran
}

\begin{abstract}
ABSTRAK
Penelitian ini bertujuan untuk mengukur pengaruh terpaan informasi riset di Pusat Penelitian Elektronika dan Telekomunikasi LIPI melalui website www.ppet.lipi.go.id terhadap sikap mahasiswa mengenai penelitian. Tujuan penelitian ini untuk mengetahui besarnya pengaruh jumlah waktu yang digunakan dalam mengakses informasi terhadap sikap mahasiswa mengenai penelitian, isi pesan terhadap sikap mahasiswa mengenai penelitian, dan hubungan individu dengan media terhadap sikap mahasiswa mengenai penelitian. Penelitian ini menggunakan metode kuantitatif dengan analisis jalur. Hasil penelitian ini menunjukan bahwa secara keseluruhan terpaan informasi riset melalui website www.ppet.lipi.go.id berpengaruh secara signifikan terhadap sikap mahasiswa Teknik Telekomunikasi Telkom University mengenai penelitian. Secara parsial, hasil penelitian menunjukkan bahwa variabel jumlah waktu yang digunakan dalam informasi dan variabel hubungan individu dengan media memberikan pengaruh yang siginifikan terhadap sikap mahasiswa mengenai penelitian. Sedangkan variabel isi pesan tidak memberikan pengaruh yang siginifikan karena memberikan pengaruh yang sedikit. Kesimpulan pada penelitian ini menunjukan bahwa secara keseluruhan informasi riset telah melakukan terpaan cukup besar terhadap sikap mahasiswa jurusan Teknik Telekomunikasi Telkom University mengenai penelitian yang mengakses website www.ppet.lipi.go.id.
\end{abstract}

Kata-kata Kunci: Terpaan, informasi, media, website, sikap

\section{INFLUENCE OF RESEARCH INFORMATION EXPOSURE THROUGH WEBSITE www.ppet.lipi.go.id TOWARDS STUDENT ATTITUDES REGARDING RESEARCH}

\section{ABSTRACT}

This study aims to measure the impact of research information exposure at Research Center of Electronics and Telecommunications LIPI through the website www.ppet.lipi.go.id towards the student attitude regarding research. The purpose of this study is to determine the influence of the amount of time spend in accessing information on the attitude of the student regarding research, to know the value of message contents on the attitude of student regarding research, and to determine the influence of the individual relationship with the media on student attitude regarding research. This study uses quantitative method with path analysis. The results indicate that in overall the exposure of research information via the website www.ppet.lipi.go.id is significantly affect the telecommunication engineering student attitude of Telkom University regarding research. Partially, the results showed that the amount of spent time variable in information and the individual relationship variable with the media giving a significant influence on student attitude regarding research. While the message contents variable does not give a significant effect according to small influence result. The conclusions on this research shows that in overall research information has been doing fairly large exposure to the attitude of student majoring in Telecommunication Engineering Telkom University regarding research who access the website www.ppet.lipi.go.id.

Keywords: Exposure, information, media, websites, attitude

Korespondensi: Noorfiya Umniyati, M.I.Kom. Pusat Penelitian Elektronika dan Telekomunikasi - Lembaga Ilmu Pengetahuan Indonesia. Jl. Sangkuriang, Komplek LIPI, Gd. 20, Cisitu, Dago, Coblong, Kota Bandung, Jawa Barat 40135.e-mail: noorfiya21@gmail.com 


\section{PENDAHULUAN}

Informasi mengenai riset yang dimiliki oleh PPET LIPI perlu untuk disebarluaskan kepada publik. Salah satu media yang digunakan dalam menyebarkan informasinya adalah melalui media Internet. Pada era teknologi digital saat ini, Internet merupakan media yang mudah dijangkau oleh masyarakat. Gumilar (2014) dalam penelitiannya mengungkapkan bahwa perkembangan Internet sekarang ini berpengaruh terhadap berbagai bidang termasuk untuk menyebarkan informasi dan promosi. Salah satu bentuk media dalam jaringan Internet yang digunakan oleh PPET LIPI adalah website.

Penggunaan website oleh sivitas LIPI sebagai media informasi merupakan sebuah tahapan untuk dapat menjadikan LIPI mendapatkan prestasi di mata dunia. Seperti dalam Buku Peran LIPI Dalam Pembangunan Nasional 2010-2014 (2014: 94) diungkapkan bahwa LIPI telah mencapai sebuah prestasi dengan diakuinya LIPI sebagai salah satu lembaga penelitian terbaik di dunia. Hal ini berangkat dari penilaian salah satu software (perangkat lunak) untuk mengukur kemajuan sebuah institusi litbang dunia dengan berbagai kriteria yang ditelaah melalui website lembaga litbang tersebut yaitu Webomatric. Berikut peringkat LIPI dalam Webometrics 2009-2013:

Tabel 1 Webomatric Untuk Lembaga Riset Dunia Tahun 2009-2013

\begin{tabular}{ccc}
\hline Tahun & Peringkat & $\begin{array}{c}\text { Jumlah Lembaga } \\
\text { Riset Dunia }\end{array}$ \\
\hline 2009 & 201 & 2.000 \\
2010 & 236 & 2.000 \\
2011 & 174 & 2.500 \\
2012 & 99 & 7.562 \\
2013 & 56 & 7.562 \\
2014 & 138 & 7.506 \\
\hline
\end{tabular}

Sumber: (Peran LIPI Dalam Pembangunan Nasional 2010-2014, 2014: 94)

Untukitu LIPIterus mendorong setiap satuan kerja di lingkungan LIPI, termasuk PPET LIPI, untuk meningkatkan kinerja website masingmasing satuan kerja agar dapat menyebarkan hasil risetnya ke penjuru dunia. PPET LIPI mempunyai website yang beralamatkan di www.ppet.lipi.go.id sebagai media penyebaran informasi risetnya di bidang Elektronika dan Telekomunikasi. Menurut William dan Pei, 2001 (dalam Harmoni, 2011), keuntungan utama sebuah web adalah dimensi ketepatan waktu (timely). Informasi dapat dengan segera tersedia (real time). Menurut Ettredge (dalam Harmoni, 2011: 3), kemampuan komunikasi masal dan jangkauan global yang dimiliki oleh web memungkinkan informasi dapat diakses oleh berbagai pemangku kepentingan.

Web juga memungkinkan interaksi dua arah dan umpan balik melalui surat elektronik, forum diskusi, dan bulletin boards. Presentasi dengan menggunakan grafik, animasi dan multimedia, organisasi yang efisien melalui tautan (hyperlink), dan fasilitas pencarian dan pelacakan (search and tracking) sangat memungkinkan dilakukan pada web. Semua kelebihan tersebut membantu penyampaian informasi yang harus dikomunikasikan dari organisasi kepada masyarakat. Hasil penelitian yang dilakukan Gumilar(2014) mengungkapkan bahwa sesuai dengan sifatnya yang cepat dan dapat diakses kapan saja, frekuensi penggunaan Internet adalah paling tinggi, yaitu digunakan oleh user setiap hari.

Mahasiswa sebagai bagian dari masyarakat yang memanfaatkan hasil penelitian di LIPI. Hasil penelitian dalam bentuk publikasi ilmiah digunakan oleh mahasiswa sebagai media share education. Mahasiswa merupakan pemangku kepentingan bagi LIPI sebagai agent of change dan intangible asset dalam masyarakat yang perlu mendapatkan informasi lengkap tentang inovasi terbaru yang dilakukan oleh periset di LIPI. Pada tahun 2015, jumlah mahasiswa yang melaksanakan Kerja Praktek (KP) dan melakukan bimbingan Tugas Akhir (TA) adalah sebanyak 78 mahasiswa, yang terbanyak adalah mahasiswa jurusan Teknik Telekomunikasi Telkom University, seperti data yang tertera di dalam tabel 2.

Mahasiswa menggunakan media website PPET LIPI untuk menemukan informasi riset yang dipublikasikan oleh PPET LIPI. Informasi riset yang dikelola oleh PPET LIPI disebarkan melalui website di www.ppet.lipi. go.id. Penggunaan media oleh mahasiswa untuk memperoleh informasi riset melalui website www.ppet.lipi.go.id dapat dijelaskan oleh teori integrasi informasi (integrated information theory). 
Tabel 2 Rekap Penerimaaan Mahasiswa KP dan Bimbingan TA Tahun 2015

\begin{tabular}{lc}
\hline \multicolumn{1}{c}{ Nama Perguruan Tinggi } & Jumlah Peserta KP dan TA \\
\hline Universitas 11 Maret & 16 \\
Universitas Negeri Semarang & 2 \\
Institut Pertaniang Bogor & 4 \\
Politeknik Negeri Bandung & 7 \\
Universitas Islam Negeri & 10 \\
Universitas Gadjah Mada & 2 \\
Telkom University & 30 \\
Universitas Negeri Jakarta & 3 \\
Universitas Pendidikan Indonesia & 4 \\
\hline
\end{tabular}

Sumber: Bidang Pengelolaan dan Diseminasi Hasil Penelitian PPET LIPI Tahun 2015

Teori Integrasi Informasi merupakan teori pengorganisasian pesan yang dikemukakan oleh Martin Feishbein. Pendekatan teori ini menjelaskan bahwa bagi pelaku komunikasi berpusat pada cara individu mengakumulasi dan mengatur informasi tentang semua orang, objek, sitasi atau gagasan atau ide yang membentuk sikap atau kecenderungan untuk bersikap dengan cara yang positif atau negatif terhadap beberapa obyek (Littlejohn, 2004: 4). Hal ini menekankan bahwa pendekatan integrasi informasi adalah salah satu teori yang menjelaskan pembentukan informasi dan perubahan sikap.

Teori Integrasi Informasi terdiri atas tiga komponen yaitu informasi (information), manusia (person) dan sikap (attitude). Terpaan informasi kepada khalayak sebagai manusia akan membentuk sikap yang merupakan dari efek komunikasi itu sendiri. Menurut Rosengren (1974) dalam Kriyantono (2008), terpaan informasi melalui media dapat dioperasionalkan menjadi jumlah waktu yang digunakan dalam berbagai jenis media, isi berita media yang dikonsumsi, dan berbagai hubungan antara individu konsumen media dengan isi media yang dikonsumsi atau dengan media keseluruhan (Kriyantono, 2008: 207).

Informasi riset yang diakses melalui website www.ppet.lipi.go.id (komponen information) oleh mahasiswa jurusan Teknik Telekomunikasi Telkom University (komponen person) dan pada akhirnya akan menimbulkan efek yaitu perubahan sikap (komponen attitude). Mahasiswa jurusan Teknik Telekomunikasi Telkom University yang mengakses website www.ppet.lipi.go.id kemudian mengakumulasi dan mengatur informasi mereka dapatkan dari website. Hasil terpaan informasi riset yang mereka dapatkan dengan mengakses website maka cenderung akan merubah sikap mereka. Berdasarkan latar belakang tersebut, maka penulis tertarik untuk melakukan penelitian mengenai "pengaruh terpaan informasi riset di website www.ppet.lipi.go.id terhadap sikap mahasiswa mengenai penelitian".

Identifikasi masalah yang akan dijadikan panduan dalam penelitian ini adalah sejauh mana pengaruh jumlah waktu yang digunakan, isi pesan serta hubungan individu dengan media terhadap sikap mahasiswa jurusan Telekomunikasi Telkom University mengenai penelitian.

Penelitian ini didasari oleh Teori Psikologi Kognitif yang menjadi Grand Theory dalam penelitian ini. Psikologi kognitif adalah studi ilmiah mengenai kognisi, yang bertujuan untuk mengadakan eksperimen dan mewujudkan teori yang menerangkan bagaiamana proses mental disusun dan berfungsi dengan cara yang objektif dan ilmiah. Psikologi kognitif memandang manusia sebagai mahluk yang berfikir, merencanakan, mengambil keputusan berdasarkan informasi yang diingat, dan memilih dengan cermat stimulus mana yang membutuhkan perhatian (Atkinson, 2001: 11 dalam Syam, 2011: 91).

Teori psikologi kognitif menjadi grand theory untuk penelitian ini adalah dengan asumsi bahwa komunitas sebagai bentuk organisme menerima informasi kemudian bagaimana cara komunitas itu memperoleh informasi, lalu mengolahnya, dan selanjutnya menyimpan informasi tersebut, dan pada 
akhirnya akan menyebabkan respon. Penelitian ini ingin mengetahui pembentukan sikap, yang merupakan bentuk dari respon yang akan terbentuk.

Apply Theory pada penelitian ini adalah Teori Integrasi Informasi. Teori Integrasi Informasi merupakan teori yang dikemukakan oleh Martin Feishbein yang menjelaskan bahwa komunikator mengakumulasikan dan mengorganisasikan informasi yang diperolehnya tentang sekelompok orang, objek, situasi, atau gagasan untuk membentuk sikap yang sesuai dengan konsep yang terbentuk dari hasil penerimaan informasi tersebut (Littlejohn, 2004: 74). Asumsi dari teori adalah semua informasi mempunyai kekuatan potensial yang dapat mempengaruhi orang untuk memiliki sikap tertentu.

Teori Integrasi Informasi terbagi menjadi tiga komponen yaitu information (informasi), person (orang), dan attitude (sikap). Sikap merupakan kecenderungan untuk berperilaku positif atau negatif terhadap objek. Pendekatan Teori Integrasi Informasi menjelaskan bahwa terdapat hubungan perolehan informasi pada individu dengan sikap.

Komunikasi massa yang menggunakan multimedia dapat dikatakan sebagai media baru. Olubunmi (2016) menyebutkan bahwa

"new media is a form of interactive communication involving the use of technology and media modalities in digital technology such as Internet, podcasts, RSS feeds, social network, text messaging, blogs, wikis, virtual worlds and others. New Media makes it possible to create, modify, and share contents, using relatively simple tools that are often free or inexpensive. New media requires computer or mobile device with Internet access".

Hal ini menjelaskan bahwa media baru adalah bentuk komunikasi secara interaktif yang melibatkan pengguanan teknologi dan modalitas media di era teknologi digital seperti halnya Internet sehingga memungkinkan untuk menciptakan, memodifikasi dan menyebarkan isi pesan dengan menggunakan sarana yang mudah, gratis dan tidak mahal.

Komunikasi massa selalu berhubungan dengan transmisi dan penyebaran pesan. Saat ini terpaan dari proses komunikasi massa sangatlah masif di tengah masyarakat modern. Salah satu media massa yang digunakan adalah media online. Walaupun masih terjadi polemik di antara para ahli bahwa apakah media online termasuk media massa atau bukan, tetapi media online mempunyai sebagian besar karateristik dari komunikasi massa, seperti yang diungkapkan McQuail (2005: 78) bahwa "komunikasi massa terdiri dari lembaga-lembaga dan teknik-teknik dengan nama kelompok-kelompok khusus menggunakan peralatan-peralatan teknologi (pers, radio, film, dan sebagainya) untuk menyebarkan isi simbolik kepada khalayak yang banyak jumlahnya, heterogen dan terpisahpisah".

Terpaan informasi atau pesan terjadi apabila seseorang itu membaca, menonton, mendengar, dan kemudian timbul efek baik langsung maupun tidak langsung sehingga membentuk persepsi dalam dirinya terhadap informasi atau pesan yg menerpanya. Efek yang terjadi akan dapat terlihat pada sikap individu, apakah mengalami perubahan perilaku atau tidak. Terpaan media (media exposure) menurut Rosengren dapat dioperasionalkan menjadi jumlah waktu yang digunakan dalam berbagai jenis media, isi berita media yang dikonsumsi, dan berbagai hubungan antara individu konsumen media dengan isi media yang dikonsumsi atau dengan media keseluruhan (dalam Kriyantono, 2008: 207). Terpaan dapat dikatakan juga sebagai keadaan terkena pada khalayak oleh pesanpesan yang disebabkan media massa yang dapat dioperasionalkan menjadi jumlah waktu yang digunakan dalam berbagaijenis media (intensitas berita), isi berita media yang dikonsumsi, dan berbagai hubungan anatar individu konsumen media dengan isi media yang dikonsumsi atau dengan media keseluruhan (daya tarik berita) dalam menonton televisi, film, membaca surat kabar, portal berita online, atau majalah dan mendengarkan radio (Rakhmat, 1995: 12).

Teknologikomunikasi tidak menghantarkan atau mentransmisikan informasi; teknologi komunikasi mengubah relasi antara manusia dan dunia mereka secara fundamental, mendorong kita untuk membentuk makna baru untuk segala hal yang kita temui dengan dan melalui media.

Anwar (2014) dalam bukunya Sistem Komunikasi Indonesia menjelaskan bahwa Internet telah mengubah dunia komunikasi dengan cara yang sangat mendasar, terutama melibatkan banyak interaksi antara komunikator dengan pengguna. Melalui 
Internet, kegiatan komunikasi dapat terlaksana dengan menyertakan jutaan orang di seluruh dunia, tanpa adanya hubungan yang bersifat pribadi. Segala konteks komunikasi dengan menggunakan Internet maka yang tercipta oleh Internet tersebut sangat khas, yaitu jutaan individu yang terhubung oleh jaringan komputer, yang disebut sebagai dunia maya (cyberspace) (Anwar, 2014: 255).

Baran (2008) menguraikan hampir sangat tidak mungkin untuk mengatakan jumlah pasti pengguna Internet. Orang-orang yang memiliki komputer tidak serta merta terkoneksi dengan Internet, dan orang tidak harus memiliki komputer sendiri untuk dapat menggunakan Internet. Beberapa pengguna mengakses Internet melalui mesin di sekolah, perpustakaan, atau tempat kerja. Perkiraan baru yang terbaik mengindikasikan terdapat setidaknya 1 miliar pengguna di seluruh dunia. Tetap saja, lebih dari tiga perempat dari semua orang Amerika mengakses Internet secara teratur dari rumah.

Menurut Baran (2008) demografi Internet telah telah mengalami perubahan dramatis dalam beberapa tahun terakhir ini. Contohnya, pada tahun 1996, 62\% pengguna Internet di Amerika adalah pria. Pada tahun 2000, untuk pertama kalinya perempuan menjadi jenis kelamin mayoritas pengguna Internet. Saat ini, perempuan dari setiap kelompok umur menggunakan Internet lebih dari pria, dan tidak terlalu mengejutkan, semakin muda seseorang, semakin besar kecenderungannya untuk mengakses Internet (Baran, 2008: 234).

Situs Internet atau website memiliki kelebihan dalam menyebarkan informasi. Bagi sebuah organisasi website merupakan bentuk pemanfaatan teknologi Internet oleh organisasi untuk menyediakan informasi dan berkomunikasi secara efisien. Website organisasi merupakan sebuah media interaktif yang dapat menjangkau pembacanya dalam waktu yang singkat.

Kelebihan website bagi organsisasi yaitu dengan adanya sifat komunikasi yang cepat dan lintas batas di era digital memungkinkan beragam bentuk informasi dan jaringan kerja yang belum pernah dikenal sebelumnya; sehingga memungkinkan khalayak menjadi pengguna aktif dalam komunitas tersebut. Kelebihan lainnya adalah website organisasi menyediakan informasi secara menarik dengan kombinasi antara teks, gambar dan desain
(Prayudi, 2007: 104-114).

Sikap merupakan sebuah fenomena yang timbul karena ditentukan oleh keadaan obyek yang kita hadapi, pengalaman-pengalaman masa lalu, situasi yang kita hadapi saat ini dan harapan-harapan kita di masa yang akan datang. Berbagai macam dasar pemikiran mengenai definisi sikap telah dikemukakan dalam berbagai versi oleh para ahli. Salah satunya adalah menurut Secord dan Backman dalam Azwar (2012: 5), definisi sikap adalah keteraturan tertentu dalam hal perasaan (afeksi), pemikiran (kognisi), dan predisposisi tindakan (konasi) seseorang terhadap suatu aspek di lingkungan sekitarnya. Definisi ini berdasar pada pemikiran triadik bahwa sikap merupakan konstelasi komponen-komponen kognitif, afektif, dan konatif yang saling berinteraksi dalam memahami, merasakan, dan berperilaku terhadap suatu objek.

Sikap memiliki tiga komponen, yaitu: (1) komponen kognisi yang hubungannya dengan beliefs, ide dan konsep. Komponen kognitif dapat disamakan dengan pandangan (opini), terutama apabila menyangkut masalah yang kontroversial; (2) komponen afeksi yang menyangkut emosional seseorang. Komponen afektif merupakan perasaan individu terhadap objek sikap dan menyangkut masalah emosi. Aspek emosional inilah yang biasanya berakar paling dalam sebagai komponen sikap dan merupakan aspek yang paling bertahan terhadap pengaruh-pengaruh yang mungkin akan mengubah sikap seseorang; dan (3) komponen konasi yang merupakan kecenderungan bertingkah laku. Komponen konatif atau komponen perilaku berisi tendensi atau kecenderungan untuk bertindak atau untuk bereaksi terhadap sesuatu dengan caracara tertentu. Komponen ini didasari oleh asumsi bahwa kepercayaan dan perasaan banyak mempengaruhi perilaku. Pengertian kecenderungan berperilaku menunjukkan bahwa komponen konatif meliputi bentuk perilaku yang tidak hanya dapat dilihat secara langsung saja, akan tetapi meliputi pula bentukbentuk perilaku yang berupa pernyataan atau perkataan yang diucapkan seseorang. (Mar'at, 1982: 13). Sikap pada hakikatnya adalah kecenderungan perilaku seseorang terhadap lingkungannya. Sikap juga dapat diartikan sebagai reaksi seseorang atas stimulus yang datang kepada dirinya. 


\section{METODE PENELITIAN}

Penelitian ini menggunakan pendekatan kuantitatif. Jenis penelitian yang digunakan adalah penelitian deskriptif (descriptive study). Penelitian deskriptif menurut Sugiyono (2008: 35) adalah penelitian yang berkenaan dengan pertanyaan terhadap keberadaan variabel mandiri, baik hanya pada satu variabel atau lebih (variabel yang berdiri sendiri). Jadi dalam penelitian ini, peneliti tidak membuat perbandingan variabel itu pada sampel lain, dan mencari hubungan variabel dengan variabel yang lain.

Berdasarkan topik yang diangkat dalam penelitian ini maka metode yang digunakan adalah metode survei. Penelitian dengan metode survei ditujukan pada sejumlah besar individu. Fokus perhatiannya hanya ditujukan pada beberapa variabel saja. Dengan survei peneliti hendak menggambarkan karakteristik tertentu dari suatu populasi, apakah berkenaan dengan sikap, tingkah laku ataupun aspek sosial lainnya. Metode survei digunakan dalam penelitian yaitu bertujuan untuk menjelaskan (eksplanasi), digunakan sampai pada pengujian hubungan antarvariabel, jadi tidak hanya menggambarkan karakteristik tertentu dari suatu populasi atau kelompok yang menjadi sampel penelitian (Faisal, 2005: 23).

Unit analisis dalam penelitian ini adalah mahasiswa jurusan Teknik Telekomunikasi Telkom University yang terdaftar di jurusan
Teknik Telekomunikasi Telkom University Angkatan 2013 yang sedang menempuh masa kuliah di semester 5-6 yang mana sedang menuju proses penelitian (mencari tema penelitian, mencari ide penelitian, mencari gagasan penelitian di bidang Telekomunikasi) yaitu sebanyak 114 orang. Mahasiswa Jurusan Telekomunikasi Fakultas Teknik Universitas Telkom merupakan mahasiswa yang paling banyak melamar ke Pusat Penelitian Elektronika dan Telekomunikasi LIPI untuk melakukan bimbingan Tugas Akhir ataupun Kerja Praktek dibandingkan dengan mahasiswa dari Perguruan Tinggi lainnya.

Sampel dalam penelitian ini menggunakan teknik simple random sampling atau sampel acak sederhana. Diketahui jumlah populasi mahasiswa jurusan Teknik Telekomunikasi Telkom University Angkatan 2013 adalah sebanyak 114 orang dan tingkat presisi yang ditetapkan dalam penelitian ini sebesar 10\%. Maka berdasarkan perhitungan rumus Taro Yamane, maka jumlah sampel dalam penelitian ini adalah 53 responden.

Teknik analisis data pada penelitian ini adalah dengan menggunakan Teknik analisis deskriptif dan Teknik analisis jalur. Analisis jalur digunakan tujuannya untuk dapat menghitung hubungan langsung dan tidak langsung dari variabel bebas terhadap variabel terikat. Hubungan ini tercermin dalam koefisien jalur (path coefficient) yang sesungguhnya adalah koefisien regresi yang telah dibakukan.

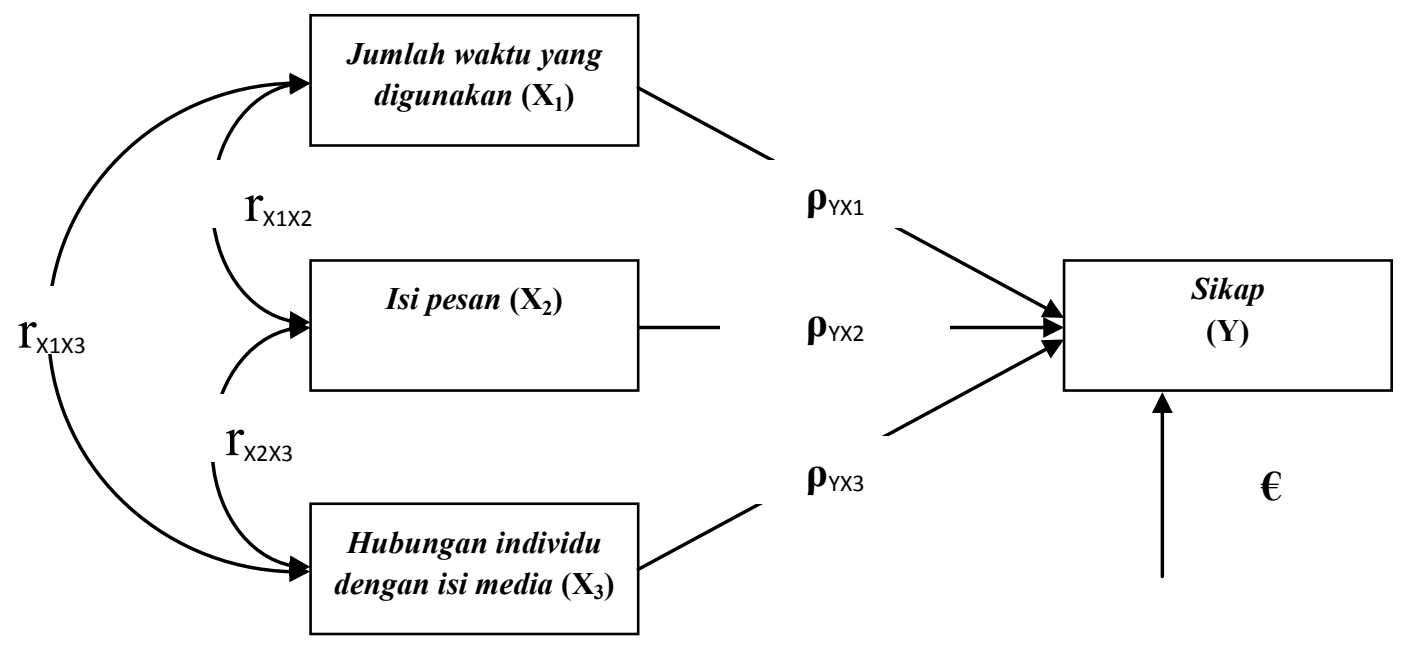

\section{Gambar 1 Diagram Jalur Variabel Penelitian}

Keterangan:

$\mathrm{X} 1=$ Jumlah waktu yang digunakan dalam informasi

$\mathrm{X} 2=$ Isi pesan

$\mathrm{X} 3=$ Hubungan individu dengan isi media

$\mathrm{Y} \quad=$ Sikap 


\section{HASIL DAN PEMBAHASAN}

Hasil penelitian secara keseluruhan menunjukkan bahwa terpaan informasi riset melalui website www.ppet.lipi.go.id telah berkontribusi positif dan signifikan terhadap sikap mahasiswajurusan Teknik Telekomunikasi Telkom University angkatan 2013 yang mengakses website PPET LIPI www.ppet.lipi. go.id pada saat melakukan penelitian. Informasi riset yang disajikan di website PPET dianggap berhasil mempengaruhi sikap pembacanya. Terlihat dari hasil besarnya nilai $\mathrm{F}$ hitung yang diperoleh melalui perhitungan statistik lebih besar dari F tabel, yaitu 48,669 > 2,794. Artinya mahasiswa sebagai pembaca informasi riset melalui website PPET dapat menerima dan menyambut positif informasi riset yang disajikan di dalam website. Berdasarkan hasil pengujian secara simultan, maka hasil yang didapatkan ditunjukkan oleh tabel 3.

Pada tabel 3 dapat kita ketahui bahwa hasil pengujian signifikan yang berarti Jumlah Waktu yang digunakan dalam Informasi (X1), Isi Pesan (X2) dan Hubungan Individu dengan Isi Media (X3) secara simultan memiliki pengaruh signifikan terhadap Sikap Mahasiswa (Y). Hal ini berkaitan dengan Teori Integrasi Informasi oleh Martin Fishben (Little John, 1996: 137-138) sebagai Apply Theory dalam penelitian ini, yang menyatakan bahwa orang mengakumulasikan dan mengorganisasikan informasi yang diperolehnya tentang sekelompok orang, objek, situasi, atau ide untuk membentuk sikap yang sesuai dengan konsep yang terbentuk dari hasil penerimaan informasi tersebut.

Dari teori ini dapat kita buktikan bahwa ketika informasi mengubah sikap mahasiswa secara kuat, hal ini disebabkan karena khalayak mempelajari informasi yang dilihatnya yang kemudian akan mengarah ke perubahan sikap, apakah informasi riset yang disajikan akan mempengaruhi sikap mahasiswa menjadi positif atau negatif.

Proses perubahan sikap khalayak dimulai ketika informasi (Ad Exposure) menyentuh kesadaran, pemahaman dan pengetahuan khalayak sebagai individu (Person) yang selanjutnya menimbulkan perubahan sikap (Attitude) khalayak. Martin Fishben menyatakan bahwa semua informasi mempunyai kekuatan potensial yang dapat mempengaruhi orang untuk memiliki sikap tertentu. Besar atau tidaknya pengaruh tersebut akan tergantung pada dua hal yaitu seberapa besar informasi tersebut dapat mendukung kepercayaan yang telah dimiliki sebelumnya dan seberapa besar informasi tersebut dapat dipercayai kebenarannya (berkaitan dengan kredibilitas informasi dan sumber informasi).

Informasi yang disampaikan melalui media massa yang dalam hal ini media online akan berdampak positif tergantung pada terpaan dari setiap khalayak sasaran. Hal serupa juga dikatakan Janowitz dalam McQuail (2005: 78) bahwa "Komunikasi massa terdiri dari lembagalembaga dan teknik-teknik dengan nama kelompok-kelompok khusus menggunakan peralatan-peralatan teknologi (pers, radio, film, dan sebagainya) untuk menyebarkan isi simbolik kepada audiens yang banyak jumlahnya, heterogen dan terpisan-pisah".

Informasi sebagai pesan komunikasi akan mengubah sikap mahasiswa, disebabkan mahasiswa mempelajari konten dari informasi riset tersebut kemudian merubah sikap terhadap risetyang akan dilakukannya. Dalam Kriyantono (2008: 207) Rosengren mengemukakan bahwa terpaan oleh media (media exposure) dapat dioperasionalkan menjadi jumlah waktu yang digunakan dalam berbagai jenis media, isi berita media yang dikonsumsi, dan berbagai hubungan antara individu konsumen media dengan isi media yang dikonsumsi atau dengan media keseluruhan. Sedangkan pada pengujian secara parsial, maka hasil yang didapat ditujukkan

\section{Tabel 3 Pengujian Secara Simultan}

\begin{tabular}{cccccc}
\hline Hipotesis Alternatif & F hitung & $\mathrm{db}$ & F tabel & Keputusan & Kesimpulan \\
& & & & & \\
\hline $\mathrm{X}_{1}, \mathrm{X}_{2}$ dan $\mathrm{X}_{3}$ secara simultan & 48,669 & $\mathrm{db}_{1}=3$ & 2,794 & $\mathrm{H}_{0}$ ditolak & Signifikan \\
berpengaruh terhadap Y & & $\mathrm{db}_{2}=49$ & & & \\
\hline
\end{tabular}


Tabel 4 Pengujian Parsial

\begin{tabular}{cccccc}
\hline Hipotesis & thitung & $\mathrm{db}$ & $\mathrm{t}$ tabel & Keputusan & Kesimpulan \\
\hline $\mathrm{P}_{\mathrm{y} \times 1}=0$ & 3,066 & 49 & $\pm 2,010$ & Ho ditolak & Signifikan \\
$\mathrm{P}_{\mathrm{y} \times 2}=0$ & 1,631 & 49 & $\pm 2,010$ & Ho diterima & Tidak Signifikan \\
$\mathrm{P}_{\mathrm{y} \times 3}=0$ & 2,175 & 49 & $\pm 2,010$ & Ho ditolak & Signifikan \\
\hline
\end{tabular}

oleh tabel 4.

Dari tabel 4 dapat kita ketahui bahwa nilai t hitung untuk masing-masing variabel Jumlah Waktu yang digunakan dalam Informasi (X1) dan Hubungan Individu dengan isi media (X3) lebih besar dari nilai $t$ tabel. Ini berarti variabel Jumlah Waktu yang digunakan dalam Informasi (X1) dan Hubungan Individu dengan isi media (X3) secara parsial memberikan pengaruh yang signifikan terhadap Sikap Mahasiswa (Y). Sedangkan variabel Isi Pesan (X2) memiliki t hitung yang lebih rendah dari t tabel, artinya variabel Isi Pesan (X2) secara parsial tidak memberikan pengaruh yang signifikan terhadap Sikap Mahasiswa (Y) dikarenakan jumlahnya yang sedikit.

Ketiga aspek tersebut yaitu jumlah waktu yang digunakan dalam berita, isi pesan berita, dan hubungan individu dengan isi berita, akan mampu membentuk sikap mahasiswa. Azwar (1995: 24) menyatakan pembentukan sikap yaitu komponen kognitif yang didasari oleh pengetahuan, persepsi dan pengalaman seseorang mengenai suatu objek, komponen afektif merupakan emosi-emosi yang ada pada diri seseorang dalam kaitannya dengan suatu objek, dan komponen konatif (kecenderungan bertindak) merupakan kesiapan untuk berperilaku tertentu yang disadari oleh suatu sikap tertentu.

Website www.ppet.lipi.go.id adalah salah satu website yang menyajikan informasi riset telekomunikasi yang penelitiannya dilakukan oleh lembaga riset nasional. LIPI sebagai satu-satunya lembaga riset milik pemerintah. Untuk itu bagi mahasiswa jurusan Teknik Telekomunikasi Telkom University informasi tersebut akan menjadi sumber yang mempunyai kredibiltas tinggi untuk dijadikan sebagai referensi di bidang telekomunikasi. Untuk membaca informasi riset yang disajikan melalui website, unsur lainpun dapat mempengaruhi ketertarikan mahasiswa untuk mengunjungi website kemudian menjadikannya referensi untuk penelitiannya. Kelengkapan isi salah satunya. Menurut penuturan beberapa responden, mereka tidak menemukan informasi riset secara lengkap karena artikel atau jurnal yang disajikan di dalam website bukanlah artikel yang utuh (full paper) melainkan hanya outline dari jurnal tersebut. Selain itu responden pun menyebutkan bahwa informasi seputar organisasi tidak secara lengkap ditampilkan di dalam website. Sehingga informasi riset yang diorganisasikan (dikumpulkan) oleh pengakses website, dalam hal ini mahasiswa jurusan Teknik Telekomunikasi Telkom University, tidak selengkap yang mereka harapkan.

Secara keseluruhan, informasi riset dalam website www.ppet.lipi.go.id mempunyai pengaruh yang terhadap sikap mahasiswa. Hal ini dapat dijelaskan bahwa mahasiswa jurusan Teknik Telekomunikasi Telkom University yang mengakses informasi riset di website www.ppet.lipi.go.id tertarik pada informasi riset, khususnya riset di bidang telekomunikasi, sehingga faktor ini memiliki pengaruh yang signifikan terhadap sikap mahasiswa dalam melakukan penelitian mereka.

Pendekatan Teori Integrasi Informasi menjelaskan hubungan antara tiga komponen yaitu informasi (informasi riset), orang (Mahasiswa Jurusan Teknik Telekomunikasi Telkom University angkatan 2013), dan Sikap. Pendekatan informasi dalam bentuk terpaan informasi riset di website www.ppet.lipi.go.id dalam bentuk informasi mempunyai kekuatan potensial yang dapat mempengaruhi orang untuk memiliki sikap tertentu. Sikap inilah yang memberikan kecenderungan untuk berperilaku positif atau negatif yaitu dengan menggunakan informasi riset yang diperolehnya untuk dijadikan referensi bagi karya ilmiah yang tengah dan akan mahasiswa Jurusan Teknik Telekomunikasi Telkom University angkatan 2013 ini lakukan.

\section{SIMPULAN}

Berangkat dari hasil penelitian dan 
pembahasannya, maka kesimpulan dari penelitianiniadalahhasilpengujian secara parsial menunjukkan bahwa: (a) variabel jumlah waktu yang digunakan dalam informasi berpengaruh secara signifikan terhadap sikap mahasiswa jurusan Teknik Telekomunikasi Telkom University pada saat melakukan penelitian; (b) variabel isi pesan tidak berpengaruh secara signifikan terhadap sikap mahasiswa jurusan Teknik Telekomunikasi Telkom University pada saat melakukan penelitian. Pengaruh yang diberikan variabel ini ada tapi dalam jumlah yang kecil; dan (c) variabel hubungan individu dengan isi media berpengaruh signifikan terhadap sikap mahasiswa jurusan Teknik Telekomunikasi Telkom University pada saat melakukan penelitian.

Kesimpulan secara keseluruhan, hasil pengujian secara simultan menunjukkan terpaan informasi riset melalui website www. ppet.lipi.go.id berpengaruh secara signifikan terhadap sikap mahasiswa jurusan Teknik Telekomunikasi Telkom University pada saat melakukan penelitian. Apabila dijelaskan secara parsial dari tiap-tiap varibel terikat, variabel jumlah waktu yang digunakan dalam informasi yang memiliki kontribusi besar dalam membentuk sikap mahasiswa, diikuti dengan variabel hubungan individu dengan isi media.

Akan tetapi varibel isi pesan memberikan pengaruh yang tidak signifikan secara statistik, karena pengaruh yang diberikan variabel ini tidak terlalu besar. Hal ini menunjukkan bahwa informasi riset telah melakukan terpaan yang cukup besar terhadap mahasiswa jurusan Teknik Telekomunikasi Telkom University pada saat melakukan penelitian, terbukti dari hasil penelitian ini secara keseluruhan menunjukan hasil signifikan.

Berdasarkan hasil penelitian dan kesimpulan, maka saran yang diajukan peneliti adalah website yang difungsikan sebagai media untuk menyebarkan informasi sebuah organisasi, dalam hal ini Pusat Penelitian Elektronika dan Telekomunikasi LIPI, seharusnya dimanfaatkan secara optimal dengan meningkatkan kelengkapan informasi, mendesain tampilan semenarik mungkin, sehingga pengguna media website dapat tertarik untuk mengakses informasi yang terdapat di dalamnya secara kontinyu dan dapat memanfaatkan informasi yang ada di dalamnya secara optimal.

Selain itu, pengelola website pada organisasi pemerintahan meningkatkan kelengkapan informasi yang terdapat dalam website sehingga isi pesan yang terkandung di dalamnya akan berpengaruh secara positif kepada usernya.

\section{DAFTAR PUSTAKA}

Arifin, A. (2014). Sistem komunikasi indonesia. Bandung: Simbiosa Rekatama Media

Azwar, S. (2012). Sikap manusia, teori dan pengukurannya. Yogyakarta: Pustaka Pelajar

Baran, S. J. (2008). Pengantar komunikasi massa Jilid 1 Edisi 5, Melek Media dan Budaya. Jakarta: Erlangga

Faisal, S. (2005). Format-format penelitian sosial. Jakarta: Rajagrafindo Persada

Gumilar, G. \& Zulfan, I. (2014). Penggunaan media massa dan internet sebagai sarana penyampaian informasi dan promosi oleh pengelola industri kecil dan menengah di bandung. Jurnal Kajian Komunikasi, Vol.2 No.1. Diakses dari http://jurnal.unpad.ac.id/ $\mathrm{jkk} /$ article/view/6054/3165.

Harmoni, A. (2011). Media richness theory dan potensi website sebagai media komunikasi csr oleh perusahaan. Jurnal Elektronik, Vol.6, No. 3. Jakarta .

Katalog Dalam Terbitan. (2014). Peran lipi dalam pembangunan nasional 2010-2014. Jakarta: LIPI Press

Kriyantono, R. (2008). Teknik praktis riset komunikasi. Jakarta: Kencana Prenada Media Group

Olubunmi, A. P. (2016). The emerging cyber media: the beginning of a new media and the end of old media. Online Journal of Communication and Media Technologies, Vol. 6, Issue 1.

Littlejohn, S. W \& Foss, K. A. (2005). Theories of human communication. Thomson Wadsworth

Mar'at. (1982). Sikap manusia perubahan dan pengukurannya. Jakarta: Ghalia Indonesia

McQuail, D. (2005). Teori komunikasi massa. Jakarta: Erlangga.

Prayudi. (2007). Penulisan naskah public relation. Yogyakarta: Penerbit Andi

Rakhmat, J. (1995). Psikologi komunikasi. Bandung: Remaja Rosdakarya

Syam, N. W. (2011). Psikologi sebagai akar ilmu komunikasi. Bandung: Simbiosa 
Rekatama Media

Tresnawati, Y. (2014). Modul kapita selekta sosial komunikasi. Jakarta: Universitas Mercuabuana 